Teosofia: Indonesian Journal of Islamic Mysticism

Volume 6, Number 2, 2017: 109-120 DOI: 10.21580/tos.v6i2.3385

\title{
Exploring the Connections between Spirituality and Morality: Phenomenology Study on Tijaniyyah Sufi Order's Congregation in Jatibarang Brebes
}

\author{
Saepudin \\ Sekolah Tinggi Agama Islam Bakti Negara (STAIBN) Tegal \\ atep71@gmail.com
}

\begin{abstract}
This article aims at revealing the connections between aspects of spirituality and morality which are able to present happiness and tranquility. One of them is through the approach implicitly implemented in aurad ritual, which is performed by Tijaniyyah sufi order's congregation at Jatibarang Brebes. It has proven to breaking down the value of the community from bad to good. This phenomenological study, investigates the emergence of the congregation was caused over the human behavior decadence in the midst of modern society. System carried out by Tijaniyyah in renewing the morality of society following the manhaj of prophet Muhammad i.e. through akhlakiyah (ethic) approach. To prove the truth of this Tijaniyyah mission against the moral improvement of society, congregations do a ritual that is lazimah dan wadifah which aims at forming behavior change, especially on its followers. The results of this study show that Tijaniyyah's congregations at Jatibarang Brebes assert the existence of a sense of serenity in their own life. In addition, they always istiqamah (consistent and commitment) in dealing with any mundane problem.
\end{abstract}

Keywords: spirituality; morality; human behaviour; Tijaniyyah

\section{A. Introduction}

$\mathrm{E}$ very human has basically born in the primordial condition of nature. He looks like a white paper that has not been tainted by any any thing. Essential human sanctity according to Hamka as quoted by Haris caused by human elements spiritually, is God's light that spark. Similar with the opinion he was, that in human nature, according to Aham has good potential (potential goodness). Later in development, these natures affecting other elements, such as lust (desire) that function takes on a whim (iradah) to do the deed. While human performance there is good and there's bad ones, according to Mujib depending on the dominance of personality. If the dominating personality of mutmainnah, or for Aham is called as satisfied consciousness, 
then it becomes a virtue. But if human beings are dominated by the personality of anger (evil consciousness), then the low deeds will arise.

Good and bad behavior according to Ahmad Amin is essentially caused by the habit. Therefore good habits need to intensively support-got to be always consistent. This can be attempted through the motivation of religious experience (religious experiences) in the form of enrichment experiences spirituality religion.

Religious experience to drive someone to the lofty moral can be obtained with a variety of way. Subandi argues that religious behavior one would be more, than most of the humans in General to do Dhikr. ${ }^{1}$ The experience of spirituality through dhikr will motivate against moral improvement. This research present to prove and examine the thesis or opinion on the connections between spirituality and morality through phenomenological study on Tijaniyyah sufi order's congregation at Brebes.

\section{B. Concerning Tijaniyyah Sufi Order's Congregation at Jatibarang Brebes}

\section{Historical Accounts of Tijaniyyah}

The full name of the founder of Tijaniyyah was Ahmad ibn Muhammad Ibn Ahmed Muhtar bin Ahmad bin Muhammad bin Salim bin al-' bin Salim bin Ahmad Iid alAlwani ibn Ahmad Ibn ' Ali ibn ' Abd-Allaah ibn ' Abbas bin Abdil Jabbar bin Idris bin Ishaq bin Zainal'Abidin bin Ahmad bin Muhammad an-Nafsiz Zakiyah Ibn Abdullah alKamil bin Hasan al-Mutsanna bin Hasan al-Sibti Ibn ' Ali Ibn Abi Talib from sayyidah Fatimah az-Zahra al-Batul Bint Prophet. ${ }^{2} \mathrm{He}$ was born at ' Ain Madi, a region in southern Algeria in the year 1150 a.h./1737 M., and died in Fez Morocco. He lived in the $1150-1230 \mathrm{H} / 1737-1815 \mathrm{M}$, aged 80 years. ${ }^{3}$ Named Tijani because is attributed to his homeland of a tribe namely Tijani Ain MadiAljazair region of North Africa. His father named Muhammad ibn al-Mukhtar, an alim and wara ', and his mother was named ' Aisha bint al-Atsil, a woman also alim, diligent worship, Dhikr, and always follow the Sunnah-Sunnah of the Prophet. At-Tijani had eight children, four boys and four girls. Four men named Sayyid Muhammad Habib died in Fes Morocco while still a child, Shaikh Mukhtar died of childhood, Sayyid Muhammad Kabir, and Sayyid Muhammad Habib. While her daughter was four and Zainab Sa'idah, both are twin sisters, Fathimah and 'Aisha. ${ }^{4}$

${ }^{1}$ Subandi, Psikologi Dzikir; Studi Fenomenologi Pengalaman Transformasi Religius (Yogyakarta: Pustaka Pelajar, 2009), 7.

${ }^{2}$ Hamid, Thariqah at-Tijaniyah, 59-60.

${ }^{3}$ H.A.R. Gibb et al. (ed.), Shorter Encyclopedia of Islam (Leiden-New York: E.J. Brill, 1991), 592-594.

${ }^{4}$ Muhammad bin Muhammad al-Hajuji al-Hasani, Ittihkaf Ahli al-Maratib al-'Irfaniyyah bi Dzikriba'diRijali at-Tariqati at-Tijaniyyati, Juz. I, www.cheikh-skiredj.com. 169. 
Eksploring the Connections between Spirituality and Morality ....

He was a devout religious, always guarded by God Almighty high ethical, smooth soul, wild-eyed shy with something not good, supel and bersetiakawan with anyone without picking and sorting out a friend, a diligent and seriously, obey the teacher and pious people, diligent reading Qur'an, not much to say except that it is necessary and beneficial, its vision and mission far ahead but stay humble, always giving priority to the public interest rather than the interests of the personally, he memorized the Qur'an since the minor age of seven years. ${ }^{5}$ Physically he is also not the weak, he is strong-bodied, soft-hard to sound from afar, and very strict, calling for amar ma'ruf nahi munkar.

\section{The History of Tijaniyyah at Jatibarang Brebes}

According to Shaykh al-Habib Muhammad al-Tijani al-Fas, this appears Implicitly backed by however, therefore the religious values in the middle of the life of the community. According to Ali Harazim as quoted by Hamid (1430) congregations arose in eleven Islamic precisely in the year $1196 \mathrm{~h}$. housed in Qasra Abi Samghun and Syalalah in the eastern part of the Sahara Desert though Shaykh Ibn Abbas At-Tijani. These orders are delivered directly (barzakhi) by the Prophet to Shaykh At-Tijani.

The development of Tijaniyyah in Morocco is increasingly rapidly than in its origin country; Aljazair, so get the full support of Sulaiman Maulay interested parties to strengthen his control over rongrongan political opponents. Cooperation with local rulers of harmony between Shaykh Tijani lasted until $1912 \mathrm{~m}$. form of communion is realized with prestigious opportunity to Shaykh Tijani to establish zawiyah-zawiyah in every corner of Morocco. ${ }^{6}$ At the beginning of the 20th century the Congregation is growing also in Africa and countries - other countries like Senegal, Mauritania, Guinea, Nigeria, even to the outside of Africa, including Saudi Arabia and Indonesia. ${ }^{7}$

The development of the Tijaniyyah in Indonesia until now haven't been able to note when ingress. But in this beberapaliteraturtarekat entry into Indonesia at about the beginning of the 20th century (between 1918 and $1921 \mathrm{M}$ ). Cirebon is where the first known existence Tijaniyyah movement. The development of the tijaniyyah in Cirebon was originally based in boarding school in the village Buntet Martapada Kulon. Scholars Indonesia first diploma tijaniyyah of Shaykh Ali Thayyib there are six people, among others, K.H. Abdul Wahab Sya'roni (Jatibarang Brebes).

\footnotetext{
5'Ali Harazim, Jawahir al-Ma'ani, Juz I., h. 23. See, Muhammad Ibnu Yusuf, al-Faid ar-Rabbani fi Ba'di al-Khasaissayyidina Abi 'Abbas Ahmad ibn Muhammad at-Tijani (Surabaya: Tanpa Penerbit, 1982), 7.

${ }^{6}$ John L., Esposito (ed.), Ensiklopedi Oxford Dunia Islam Modern, vol. IV (Bandung: Mizan, 2001), 44.

${ }^{7}$ Sri Mulyati, Mengenal dan Memahami Tarekat-Tarekat Muktabarah di Indonesia (Jakarta: Prenada Media, 2004), 223,
}

Teosofia: Indonesian Journal of Islamic Mysticism, Volume 6, Number 2, 2017 
Regarding the inclusion of Tijaniyyah to Indonesia, in this case Pijper gives two hints, by the presence of Shaykh 'Abd Thayyib and the teaching of Tijaniyyah in Pesantren Kulon Martapada Buntet. But when Shaykh Abdullah Thayyib come to Indonesia can not known up to now. Even Pijper himself stated two different opinions about the arrival of Shaykh 'Abd Thayyib to Indonesia. The one hand, he said that the first Shaykh Thayyib spread the tijaniyyah in Tasikmalaya, while on the other hand he said Sheikh Thayyib has come to some areas in Java before Tasikmalaya. ${ }^{8}$

The development of Tijaniyyah in Cirebon pioneered by KH. Abbas and his brother, KH. Annas. In addition to the two got a talqin in Indonesia by Shaykh Abdullah Thayyib, in 1924. KH. Annas cabled his brother KH. Abbas left for Mecca to take a talqin Tijaniyyah of Shaykh Alfa Hashim in Medina, where he studied alongside other Islamic sciences. For three years he lived in Mecca, and in 1927 he returned to Indonesia. KH. Annas spread and taught Tijaniyyah with KH Abbas initially followed orders Syatariyah by way of mengkader the kiai pesantren, so that its development faster and many of his followers. ${ }^{9}$

In some literature, Tijaniyyah mention only two scholars Buntet Cirebon as carriers and spreaders of Tijaniyyah in Indonesia. But in the fact there are four scholars in one lineage of K.H. Abdul Jamil, who also plays against the existence of Tijaniyyah in Indonesia. They were kiai, Kiai Annas, and Kiai Ilyas Akyas. It's just as devotees of kiai Ilyas, and Akyas as the Muqaddam (Murshid), not the first pioneers.

\section{System of Ritual to Improving Tijaniyyah Sufi Order's Congregation at Jatibarang Brebes}

Technically, the practice of ritual-spiritual of Tijaniyyah according to Hamid is formulated into activities that are daily (yaumiyah) is read in the morning and afternoon, with read some formula aurad. Aurad types consist of two kinds, namely aurad lazimah (its required) and aurad ihtiyariyah (its not mandatory). Aurad lazimah is a mandatory practice that should be practised by the pupil/ikhwan of Tijaniyyah consistently in accordance with time and the amount is determined. Whereas, in addition, its aurad ihtiyariyah is not required. Aurad is usually read by the followers through istighasah and other aurads forums. ${ }^{10}$

In addition to the daily rituals (yaumiyah), followers of this sufi order is also conducting a routine ritual "Senin Pon-an". These activities are conducted every Monday Pon in Brebes Regency and surrounding areas, attended by all the followers (people) who have already taken oath (bai'at) in Tijaniyyah, as well as by the lovers

${ }^{8}$ G.H. Pijper, FragmentaIslamica; Beberapa Studi tentang Islam di Indonesia Abad ke-20 (translated) (Jakarta: UI Press, 1987),82.

${ }^{9}$ Sri Mulyati, Tarekat-Tarekat Muktabarah di Indonesia, 225

${ }^{10}$ Hamid, Thariqah at-Tijaniyah, 86-123. 
Eksploring the Connections between Spirituality and Morality ....

(muhibbin). They gather in a place that has been passed to perform $d o^{\prime} a$ (prayer) and dhikr which is led by a muqaddam/Murshid both from within and outside the country. Prayers were read together, among others, blessings on Fatih Manaqib Shaykh Ahmad Tijani and the book of Faedurrabbani.

From the implementation of such rituals, there are few examples that appear in the change positive behavior, suppose the utterance Shaykh Yunus a. Hamid, a leader of Tarbiyah Zawiyah TarekatTijaniyyah Kebon Sirih, Central Jakarta, he has successfully invested drug users and the thugs through the Tarekat Tijaniyyah approach. Even among former users there are who issued the rest of the drugs of gravel stones from the throat through Allah's permission. ${ }^{11}$

Preliminary results of this study with several followers in Jatibarang Brebes Tarekat Tijaniyyah who follow the ritual-spiritual through aurad-aurad of Tijaniyyah, can encourage positive behaviour. But to form a religious action not just with the spiritual exercises, Tijaniyyah taught to implement shari'ah and the strengthening of the mua'malah built under the foundations of morals of Prophet.

For instance to know behavior change against the followers of Tarekat Tijaniyyah in Jatibarang Brebes, I had conducted interviews with a number of people from a variety of occupations. They claimed to feel the presence of the religious attitudes and attitudes change socially than before entering in this congregation. Positive impact that they feel is accomplishing the peace of soul and sincerity of the moment in any circumstances and in any place. They were trying to stubbornly avoid the bad behaviour (moral madzmumah) against the self's ego as well as to the environment. On the other hand when facing a problem, they always optimistic that she will certainly get help from Almighty God. As well as in the matter of the formation of character and attitude, she grew an attitude of discipline in worship ( $t a^{\prime} a b b u d$ ) to his God, increase the growth of social sensitivity and discipline in the spirit of working for life duniawiyah. No matter how he got that rizki felt enough to raise themselves and their families and unselfish (Javanese: ngangsa) without leaving the spirit of the work. ${ }^{12}$

\section{Tijaniyyah Practices as Motivation of the Behavior Reordering}

At the level of behavior, today humans have experienced morality crisis globally, not least in Indonesia. With globalization in all aspects, it will have an impact on reducing religious values on the one hand, while on the other hand humans are more

\footnotetext{
${ }^{11}$ Interview with Shaykh Yunus A. Hamid on the occasion of the regular dhikr of the at-Tijaniyah congregation on January 19, 2015 at Pondok Pesantren Darussalam Jatibarang-Brebes.

${ }^{12}$ Interview with Dasirun informant (street hawker in Tangerang), Mujiharto informant (Civil Servant of Dinas Pengairan and Energi Kabupaten Brebes), and informant Khoeruddin (a teacher at one of the primary schools in Brebes) during routine recitation on Monday 18 January 2015 at Pondok Pesantren Darussalam Jatibarang-Brebes.
} 
"deifying" science and technology. Unfortunately, science and technology used as a basis in determining his attitude and actions. Such conditions will deprive the spiritual values, which in turn by Stanislav Grof, M.D., \& Christina Grof ${ }^{13}$ are called spiritual emergencies, in which people will eventually return to the spiritual values of religion. As an antidote to the crisis in all aspects, according to Hamka must return to the moral values built on the belief system to God Almighty. ${ }^{14}$

The attitude of putting aside religious values will have an impact on the situation of melelamoran, incarnate toward secularization and abandon the vision of divinity. The loss of that divine vision resulted in a spiritual void and made man far from his God, even abandoning the teachings contained in religious dogma. As a result of it all, we often encounter in modern society feelings of stress, anxiety, greed, not confident, and even commit a criminal act.

Seeing the emergence of various social problems of modern society, then the aspect of spirituality becomes important to be immunized as well as a powerful and effective solution in solving the problem. In this case the Tariqa Tijaniyyah offers a set of concepts of teachings by returning to the model of the Prophet's behavior derived from the Qur'an. Let's say, about the success of propagation of the Prophet Saw in spreading Islam. According to some sources, the success of the Prophet's proselytizing is caused by the ability to transform moral values into the realm of social life (social ethical life) ${ }^{15}$, where morality becomes the main basis for the prophet in bringing the Kurais to the true religion. The prophet Saw's efforts not only rely on the side lahiriyah, but also balanced with spiritual transformation through prayer, dhikr, qiyamullail, etc., as a breakthrough from the esoteric aspect that gives the spirit of force in da'wah, thus impacting the emergence of clues (hidayah) to the surrounding community.

In generally almost all tasawuf of at-Taftazani ${ }^{16}$ teaches to the moral formation of the sublime, which is perfectively manifested in the tarekat system. Among the tarekat mu'tabar in Indonesia who became a force toward the mental revolution is the Tariqah Order. According to Shaykh al-Habib Muhammad at-Tijani al-Fas, this Tariqa appears

\footnotetext{
${ }^{13}$ Stanislav Grof, M.D., \& Christina Grof, Spiritual Emergency; When Personal Transformation Becomes a Crisis (ed.) (New York: Jeremy P. Tarcher/Putnam a Member of Penguin Putnam Inc.,1986), 233-235.

${ }^{14}$ Haris, Etika Hamka, 83.

${ }^{15}$ The Life Ethic according to Roger Walsh, M.D., includes the right speech and the right action. Two of these behaviors according to him became the spiritual essence, which has been proven to be a force by the Hindus in the 3000 years ago and also the gospel cry in Christianity. Roger Walsh, M.D., Essential Spirituality; the 7 Central Practices to Awaken Heart and Mind (New York: John Wiley \& Sons, Inc., 1999), 125-128.

${ }^{16} \mathrm{Abu}$ al-Wafa al-Ghanimi at-Taftazani, Sufi Dari Zaman ke Zaman (Bandung: Penerbit Pustaka, 1997), 10-16.
} 
Eksploring the Connections between Spirituality and Morality ....

to be motivated by the diminishing of religious values in the midst of people's lives. According to 'Ali Harazim ${ }^{17}$ as quoted by Hamid, this tharekat appeared in the eleventh century hijriyah precisely in 1196 H. held in Qasra Abi Samghun and Syalalah in the eastern Sahara Desert if Shaykh Ibn Abbas At-Tijani. This tariqa was delivered directly (barzakhi) by the Prophet to the shaykh At-Tijani. ${ }^{18}$

The Tijaniyya Order entered Indonesia sometime in the early twentieth century (between 1918 and $1921 \mathrm{CE}$ ). Cirebon is the first place known by the Tijaniyyah movement. The development of the Tijaniyyah congregation in Cirebon was originally centered at Pesantren Buntet in Martapada Kulon Village. The early Indonesian scholars received the first Tariqa certificate from the Shaykh Ali Toyyib there were six people, among others K.H. Abdul Wahab Sya'roni (Jatibarang-Brebes). The Jatibarang-Brebes region became an integral part of the development of the Tariqah in Indonesia.

\section{Tijaniyyah and Behavioral Reordering}

This paper captures the moral reform of Tariqah congregation of worshipers related to the implementation of religious values to the individual (self-behavior) and its relation to social-society (social interaction). To be able to know the positive and negative behavior, of course many of the methods used as a theoretical basis in assessing the good of a deed, one of the methods are through spiritual experience. In this case the spiritual experience according to Hamid, became theoretically as well as practical basis to form a person's behavior to the embodiment of noble character. While the method of spiritual practice (riyadhah) in the arrangement of the heart and soul to build a sincere nature, away from the deplorable nature, decorate yourself with the properties of praise, patience, tawadhu, qanaah, ridha and so forth, can be pursued by spiritual practice such as wirid , do'a, ratib, istighasah, and so forth formulated in tarekat. ${ }^{19}$

Furthermore, Hamid argues that all tarekat-including Tijaniyyah-is a subdivision of the Sufism discipline as a method of self-approach to Allah. In subsequent developments the scholars included auliya formulating specific methods such as wirid practices, rats, and so on. Specific deeds with all his methods are then called tarekat. Said by Jalaludin, tarekat is the path that must be taken by a Sufi to get closer to Allah. At-Taftazani argues that Sufism is generally defined as a mental revolution, by Ibrahim Basyuni as quoted by Amin Gratitude categorized as the level of Mujahadah, which is seriously put forward morals and charity in the approach of self to God. So in the level of Mujahadah,

\footnotetext{
${ }^{17}$ Is a cleric of followers of the Tijaniyah order who authored the book "Javanese al-Ma'ani fi FaidhiSayyidina Abi al-'Abbas at-Tijani". In this book Harazim writes about Sheikh Tijani and the concept of tarekat. The book is published by Dar-al-Rasyad al-Haditsah, Morocco.

${ }^{18}$ Hamid, Thariqah at-Tijaniyah, 62.

${ }^{19}$ Hamid, 17.
} 
almost all schools of Sufism lead to mental revolution, the execution of the noble to God in vertical as well as to creatures horizontally. ${ }^{20}$

Mujahadah phase (earnest and charitable) is the phase passed by all followers of the tarekat. According to Al-Harazim ${ }^{21}$ the teachings of the Tarekat Tijaniyyah principle to the teachings that uphold the moral values rely on the Prophet's morals from various aspects. That is to follow all the actions of the Prophet (peace and blessings of Allah be upon him) from the side of speech, deed, and determination. There is even a sharper statement from a Muqaddam (counselor) of tarekat Tijaniyyah, that "this Tarekat has similarities or resemblances that are very close to al-Islam in terms of manhaj, ie using the steps (manhaj) of the Prophet, including the way of propaganda. This statement is affirmed by Shaykh Yunus A. Hamid, ${ }^{22}$ that the step (manhaj) of tarekat Tijani cannot get out of manhaj Rasulullah. 'Arabi states in his work Bughyatul Mustafidin about the pattern of behavior in this order, that heaven will be obtained by faith, but faith must be implemented in the form of sharia and adorned with good morals or behavior. ${ }^{23}$

The steps and ways of propaganda of the Prophet were made a core reference by tarekat Tijaniyyah in mental development using a moral and moral approach. One example is when the Messenger of Allah (PBUH) faced the kafir of Qurays in the first decade of his preaching, to conquer the Makkah city 'thugs' through bai'at into Islam, from the bai'at radiated the light of iman and light of akhlakiyah to themselves to become great companions, such as the companions of Umar bin Hattab, Salman alFarisi, and so forth.

According to al-Fas and Hamid, the Tijaniyyah order believed full of religious information about the emergence of the Mujaddid (reformer) in the 100-year cycle. ${ }^{24}$ They think that the rays of akhlakiyah in these last days have dimmed. Shaykh Ahmad At-Tijani is a mujaddid figure that appears in the cycle that can emit the rays to bring humanity towards the strengthening of beliefs (Imaniyah), ta'abbud, and the strengthening of behavior change (mu'amalah). The reinforcement basis for resynergizing the three entities is the word of Allah. Surat An-Nisa verse 1.

${ }^{20}$ Hamka, Tasawuf Modern (Jakarta: Panjimas, 1990).

21، Ali Harazim, Jawahir al-Ma’ani, Juz I., 14

${ }^{22}$ Is a follower of Tarekat Tijaniyah who is now the Nanny of Education Foundation and Da'wah "Tarbiyah At-At-Tijaniyah Kebon Sirih-Menteng- Central Jakarta. He also wrote the book "Tharikah At-At-Tijaniyah; in the Qur'an and As-Sunnah Balance Sheet. Published by his own foundation in 2009.

${ }^{23}$ Muhammad al-'Arabi al-'Umari at-Tijani, Bughyah al-Mustafid (Brebes: Maktabah Darussalam, tt. .).40-48.

${ }^{24}$ The results of interviews with Shaykh al-Habib Muhammad at-Tijani al-Fas and Shaykh Yunus Hamid on the dhikr event together with the Tijaniyah order on January 18, 2015 at Pondok Pesantren Darussalam Jatibarang-Brebes. 
Eksploring the Connections between Spirituality and Morality ....

The object of this paper is human behavior based on the motivation of religious experience through the methods of spiritual exercises in the institution of the path. Then religious psychology becomes very important in making the basis for knowing attitudes and behavior psychologically. Psychology according to Zakiyah Darajat (1970) as quoted by Jalaludin serves to study the symptoms of normal human soul, while religion is a belief that affects attitudes and behavior. ${ }^{25}$

Psychologists agree that one of the needs of a person's sense of religion is based on human nature. Bernard's religious nature, is driven by religious instincts in human beings. The purpose of the religious commitment is, in general, to gain a happy life. To know the nature of religiosity to a person, it is necessary to examine further the existence of humanity itself and religion as an element of dependence on human needs. According to Fredrick Schleimacher (in Jalaludin), that which is the source of religion is a sense of dependence on the absolute (sense of dependent). Man feels himself weak so want to depend on the tremendous supernatural outside himself. So religion becomes an absolute instrument as a solution when humans experience stress, anxiety, and loss of control that makes powerless. ${ }^{26}$

Some sociologists who concentrate on researching religion from a sociological perspective also say the same thing. Kluchon ${ }^{27}$ argues about the role and function of religion in Religion Approaching. He said that when humans meet in a state where he is impasse, this is where religion becomes the point where spiritual guidance is the solution in pointing to calmness and optimism.

Spirituality is as part of a person's religious experience inseparable in determining to noble values. ${ }^{28}$ Jalaludin interpreted spirituality as the inner potential of man that can encourage humans to do well. Therefore, tarekat aspect - including tarekat Tijaniyyah as an institution that serves to guide to moral renewal is also used as the basis in this research.

To strengthen the basis of the study as the subject of spirituality motivation in moral renewal, the aspect of religious experience through dhikr becomes a significant basis for study. So the practices of spirituality in the form of rituals in the Tariqah Tariqah such as daily dhikr (yaumiyah), monthly (syahriyah), and others will become clear in this study.

\footnotetext{
${ }^{25}$ Jalaludin, Psikologi Agama, 8-12.

${ }^{26}$ Jalaludin., 48.

${ }^{27} \mathrm{He}$ is an anthropologist who once wrote myths and rituals in people's lives in religion Approaching. See, Saepudin, Papers, review on Clyde Kluchkhon's writing in Religion Approaching, Semarang: PPS Walisongo, 2011.

${ }^{28}$ Jalaludin, Psikologi Agama, 289.
} 


\section{Conclusion}

The foundational basis of moral building is religious values, in addition to the prevailing common values within a community. Religion became a powerful solution to the problems of modern society when nothing else could be moored. Among the ways (manhaj) that can be taken to build human morality is through a tarekat approach that is conditioned with spirituality.

The Tijaniyyah Order is one of the institutions whose work is to build morality through ruhaniyah exercises. The local study of the Tijaniyyah order in Jatibarang Brebes with a spiritual approach through daily ritual (yaumiyyah) can make a positive boost to moral change. Confession of Tijaniyyah who seriously perform the ritual, feel there is peace in life and more patient in facing all problems.

\section{Bibliograpy}

Abdul Haris, Etika Hamka; Konstruksi Etik Berbasis Rasional Religius, Yogyakarta: LKiS, 2012.

Abdul Mujib, Kepribadian dalam Psikologi Islam, Jakarta: PT. RajaGrafindo Persada, 2007.

Abu al-Wafa al-Ghanimi at-Taftazani, Sufi dari Zaman ke Zaman; Bandung: Penerbit Pustaka, 1997.

Ahmad Amin, Etika (Ilmu Akhlak), Jakarta: Bulan Bintang, 1975.

Ahmad Mahmud Subkhi, Filsafat Etika; Tanggapan Rasionalis dan Intitusionalis Islam, Jakarta: PT. Serambi Ilmu Semesta, 2001.

'Ali Harazim, Jawahir al-Ma'ani wa Bulugh al-Amani; Fi Faidh Sayyidi Abi al-'Abbas at-Tijani, Juz I. al-Maghribi: Dar al-Rasyad al-Haditsah, n.d.

Amin Syukur, Menggugat Tasawuf; Sufisme dan Tanggung Jawab Sosial Abad 21, Yogyakarta: Pustaka Pelajar, 1999.

Andre Sponville-Comte, Spiritualitas Tanpa Tuhan, Ciputat-Tanggerang: Pustaka Alvabet, 2007.

G.H. Pijper, Fragmentalslamica; Beberapa Studi Tentang Islam di Indonesia Abad ke 20, (terj.), (Jakarta: UI Press, 1987).

H.A.R. Gibb et al. (ed.), Shorter Encyclopedia of Islam, Leiden-New York: E.J. Brill, 1991).

Hamka, Tasawuf Modern, Jakarta: Pustaka Panjimas, 1990.

Henry Bayman, The Secret of Islam; Love and Law in the Religion of Ethics, Berkeley, California: North Atlantic Book, 2003. 
Eksploring the Connections between Spirituality and Morality ....

Jalaludin, Psikologi Agama; Memahami Perilaku dengan Mengaplikasikan Prinsipprinsip Psikologi, Jakarta: PT. RajaGrafindo Persada, 2015.

John L., Esposito (ed.), Ensiklopedi Oxford Dunia Islam Modern, Jilid IV, (Bandung: Mizan, 2001).

M. Yunus A. Hamid, Thariqah At-Tijaniyyah; Dalam Neraca al-Qur'an dan As-Sunnah, Jakarta: Yayasan Pendidikan dan Dakwah Tarbiyah at-Tijaniyyah, 1430 H..

Muhammad al-'Arabi al-'Umari at-Tijani, Bughyah al-Mustafíd, (Brebes: Maktabah Darussalam, tt.).

Muhammad bin Muhammad al-Hajuji al-Hasani, Ittihkaf Ahli al-Maratib al-'Irfaniyyah bi Dzikri ba'di Rijali at-Tariqati at-Tijaniyyati, Juz. I, www.cheikh-skiredj.com.

Muhammad Ibnu Yusuf, al-Faid ar-Rabbani fi Ba'di al-KhasaisSayyidina Abi 'Abbas Ahmad ibn Muhammad at-Tijani, (Surabaya: Tanpa Penerbit, 1982).

Roger Walsh, M.D., Essential Spirituality; the th Central Practices to Awaken Heart and Mind, New York: John Wiley \& Sons, Inc, 1999.

Saepudin, "Review atas tulisan Clyde Kluchkhon dalam Religion Approaching", Semarang: PPS Walisongo, 2011.

Sri Mulyati, Mengenal dan Memahami Tarekat-tarekat Muktabarah di Indonesia, Jakarta: Prenada Media, 2004.

Stanislav Grof, M.D., \& Christina Grof, Spiritual Emergency; When Personal Transformation Becomes a Crisis (ed.), New York: Jeremy P. Tarcher/Putnam a Member of Penguin Putnam Inc., 1986.

Subandi, Psikologi Dzikir; Studi Fenomenologi Pengalaman Transformasi Religius, Yogyakarta: Pustaka Pelajar, 2009.

Taufik Pasiak, Tuhan dalam Otak Manusia; Mewujudkan Kesehatan Spiritual Berdasarkan Neurosains, Bandung: PT. Mizan Pustaka, 2012.

Thomas Patrick Hughes, Dictionary of Islam; Being a Cyclopedia of the Doctrines, Rites, Ceremonies, and Custom, Together with, the Technical and Theological Terms, of The Muhammadan Religion, New Delhi-India: Cosmo Publication, 1982.

Interview with Dasirun informant (street hawker in Tangerang), Mujiharto informant (Civil Servant of Dinas Pengairan and Energi Kabupaten Brebes), and informant Khoeruddin (a teacher at one of the primary schools in Brebes) during routine recitation on Monday 18 January 2015 at Pondok Pesantren Darussalam Jatibarang-Brebes.

Interview with Shaykh al-Habib Muhammad at-Tijani al-Fas and Shaykh Yunus Hamid on the dhikr event together with the Tariqah Tijaniyyah on January 18, 2015 at Pondok Pesantren Darussalam Jatibarang-Brebes. 
